\title{
Grand challenges in urban ecology
}

\author{
Diane E. Pataki * \\ Department of Biology, University of Utah, Salt Lake City, UT, USA \\ Keywords: urban ecology, urban planning, built environment, urban design, ecology
}

The field of urban ecology has seen a major expansion in the last two decades. As the world rapidly urbanizes, human settlements constitute one of the few ecosystems on earth that are significantly increasing in their extent. As a result, interest from both the scientific community and society at large has turned its attention to the functioning of cities and their impacts on larger regions, global resources, and human well-being. Yet, urban ecosystems are fundamentally different from their natural counterparts in the dominant influence of human actions, both intentional and unintentional, on ecosystem function. While the term urban ecology is attributed to the Chicago School of sociology (Park et al., 1925), interdisciplinary, ecological studies of human settlements worldwide were facilitated most widely by UNESCO's Man and the Biosphere Program in the 1970's, and two decades later by the establishment of urban sites in the U.S. National Science Foundation's Long-Term Ecological Research Network (Sukopp, 2002; McDonnell, 2011; Formann, 2014). The resulting studies of urban-rural gradients, urban mass and energy budgets, and the "ecology of cities" have led to rapid development of methods and conceptual frameworks for integrating the social and natural sciences in the study of cities as ecosystems (Pickett et al., 2001; Alberti et al., 2003; Grimm and Redman, 2004; Moffett and Kohler, 2008; Chowdhury et al., 2011; McDonnell, 2011; Pataki et al., 2011a). While many early studies of urban ecosystem structure and function were case studies of individual cities and specific urban ecological processes, there are an increasing number of cross-city comparisons that are facilitating a new, synthetic understanding of the causes and consequences of urbanization and the complex interactions among urban ecosystem components (Loram et al., 2008; Kennedy et al., 2009; McDonnell et al., 2009; Chowdhury et al., 2011; Kendal et al., 2012; Jenerette et al., 2013; Ahern et al., 2014; Groffman et al., 2014).

While urban ecology is poised to make new breakthroughs in the functioning of complex, human-dominated ecosystems, the potential to translate scientific advances to practical applications has never been greater. Cities worldwide are struggling with a myriad of environmental and social problems as growing cities face air, water, and soil pollution, resource depletion, and aging infrastructure. As a result, there is renewed interest in developing and testing new solutions to these problems, with an increasing emphasis on approaches that apply ecological principles such as green infrastructure (Gill et al., 2007; Tzoulas et al., 2007), habitat preservation and connectivity (Rudd et al., 2002; Breuste, 2004; Goddard et al., 2010; Hostetler et al., 2011), urban metabolism (Newman, 1999; Kennedy et al., 2011; Pincetl et al., 2012; Shahrokni et al., 2015), and ecological footprints (Luck et al., 2001; Jin et al., 2009). Cities are increasingly the focus of biodiversity inventories (Hermy and Cornelis, 2000; Loram et al., 2008; Clarke et al., 2013), measurements of greenhouse gas concentrations and fluxes (Velasco and Roth, 2010; McKain et al., 2012), and monitoring of the performance of green roofs, bioswales, and other green infrastructure (Mazer et al., 2001; MacIvor et al., 2011; Lundholm et al., 2014). The challenge going forward will be to apply an increasingly advanced and nuanced understanding of urban ecology in the practice of planning, designing, and monitoring cities as dynamic ecosystems.

Such applications are a test of both the depth and breadth of our understanding of urban ecosystem processes. Unlike natural ecosystems, cities contain many ecosystem components that are almost entirely human-constructed. Building robust ecosystems that can withstand 
environmental change and avoid negative, unanticipated consequences of modifying the environment requires a systemslevel understanding of ecosystem complexity, thresholds, and feedbacks (Lovell and Johnston, 2009; Ahern, 2013). In the built and engineered environment, natural and biotic processes that have generally been termed "ecosystem services" must be translated into specific design and performance elements and metrics at the appropriate scales if ecological approaches are to be successfully used to mitigate pollution, conserve biodiversity, improve human health, and enhance human well-being (Alberti, 2007; Oberndorfer et al., 2007; Syrbe and Walz, 2012; Ahern, 2013). Moving forward, urban ecologists face a new set of challenges as the field transitions into the next phase of understanding cities and human settlements from an ecological perspective. Here, I briefly summarize three of these grand challenges. This list is not exhaustive, but highlights some key impactful, emerging areas of current research in urban ecology.

\section{Developing the Science of the Built Environment}

Cities are often described as "novel" ecosystems which had no natural analog prior to the worldwide expansion of the urban population (Hobbs et al., 2006, 2009; Kowarik, 2011). Definitions of novel ecosystems and their implications are still debated (Seastedt et al., 2008; Higgs, 2012; Morse et al., 2014; Murcia et al., 2014); nevertheless, urban ecosystems contain a broad range of distinct microenvironments and biological assemblages, from remnant natural ecosystems to almost completely human built and constructed environments. While ecology has a centurylong history of theorizing the processes that lead to the assembly and function of non human-dominated ecosystems, the extent to which such theories can be applied to designed and constructed ecosystems is still actively debated (Niemelä, 1999; Grimm et al., 2000; Kaye et al., 2006; Moffett and Kohler, 2008). The term "built" environment can refer to many different ecosystem components, some of which are analogs for natural ecosystems but with largely exotic flora and fauna and highly modified or imported soil materials (i.e., lawns and planted gardens). The built environment can also be dominated by abiotic components, i.e., concrete, asphalt, and other building materials. However, even largely abiotic environments have been shown to have a diverse microbial flora, with unknown impacts on larger scale ecosystem function or human health (Kembel et al., 2012; King, 2014; Konya and Scott, 2014).

We have made enormous progress in understanding the mechanisms underlying the structure and function of ecosystems in which humans play a small or indirect role. In urban ecology, a key next step is to gain an equally thorough understanding of constructed ecosystems. It's somewhat ironic that even though many components of urban ecosystems are built by humans, these constructed systems are often poorly understood from an ecological perspective. The factors that determine their biodiversity, community structure, and mass and energy cycles and flows can be quite uncertain, whether considering the ecology of ornamental gardens (Kareiva et al., 2007; Loram et al., 2008) or full accounting of matter and energy flows at varying scales (Moffett and Kohler, 2008; Kennedy et al., 2011; Pincetl et al., 2012). There is a particular need to consider the linkages among the built and biotic components of cities (Pickett and Cadenasso, 2008). Within the challenge of developing a new science of the built environment, specific questions include: what are the processes that lead to observed biological assembles and biodiversity in the built environment? How does ecosystem structure and function interact in the built environment? How does built ecosystem structure and function respond to environmental and social changes? It will be essential to fill in key data gaps in these areas going forward, and to use these data to develop robust conceptual and theoretical frameworks for understanding the ecology of built and constructed ecosystems.

\section{The Urban Environment and Human Well-being}

Cities are ostensibly built to enhance well-being. Both the built and non-built environments have numerous interconnections to well-being; the ecosystem services concept was developed specifically for this reason, as it asserts that "ecosystems are essential for human well-being through their provisioning, regulating, cultural, and supporting services" (Millennium Ecosystem Assessment, 2003). Yet, despite a growing literature on ecosystem services in both natural and urban systems, the precise nature of the relationship between many of the interacting processes categorized as ecosystem services and human well-being remains elusive at key spatial and temporal scales (Carpenter et al., 2009; Summers et al., 2012; Reyers et al., 2013), and this uncertainty is exacerbated in cities (van Kamp et al., 2003; Jorgensen and Gobster, 2010). Even when urban landscapes are constructed for specific purposes, such as recreation, beauty, and climate mitigation, their direct impacts on well-being often remain unknown (Cameron et al., 2012). This can be a matter of scale; carbon sequestration, for example, a commonly cited ecosystem service, directly affects quality of life only when its impacts occur on a large enough spatial scale to significantly affect atmospheric $\mathrm{CO}_{2}$ concentrations and their role in the climate system (Pataki et al., 2006). Similarly, there may be time lags between provisioning or degradation of ecosystem services and their impacts on well-being (RaudseppHearne et al., 2010). However, in the urban environment, the relationship between the many facets of human well-being and aspects of ecosystem structure and function are often uncertain, in part, because they have not yet been adequately studied in constructed ecosystems.

Thus, there are myriad studies showing that the presence of urban vegetation improves human health as quantified in several different ways, including accelerated recovery from stress and illness, increased physical activity, cognitive function, emotional health, and other metrics (Tzoulas et al., 2007; Lee and Maheswaran, 2011; Shanahan et al., 2015). However, the exact mechanisms underlying these relationships are still uncertain, 
and we do not yet know which aspects or types of vegetation provide the greatest benefits. Clarifying and contextualizing the relationships between aspects of well-being and specific facets of the urban environment is a key future challenge. Niemelä (2014) pointed out that the underlying mechanisms are likely to be inherently local; yet the answers to these questions are of interest worldwide. Sub-questions include: Are there greater physiological and psychological benefits of certain types of flora and fauna? Does it matter how many and which species are present? Does the configuration and size of parks and public greenspace vs. private gardens have a direct influence on well-being? Are there unanticipated consequences of reducing distributed and private greenspace in the urban core as cities grow denser, or can centralized public parks provide the same benefits? Intriguingly, there is evidence that perceptions of urban biodiversity are more aligned with well-being than actual biodiversity (Dallimer et al., 2012). Furthermore, there are many costs and potentially negative outcomes of replacing natural ecosystems with constructed ecosystems. Also called "ecosystem disservices," these costs are generally under-studied, but include monetary costs, resource depletion, pollution, biodiversity loss, and negative health outcomes (Lyytimäki et al., 2008; Pataki et al., 2011b; von Döhren and Haase, 2015). This has led to the pervasive question: how can tradeoffs between various ecosystem services and disservices be optimized to lead to desired outcomes for human well-being? These questions require additional and more nuanced studies of human-environment interactions across cities, regions, and populations, as the answers are critical for translating urban ecosystem science into practice.

\section{Ecology to Inform Urban Planning and Design}

Given that the complex interactions among ecosystem components in the built environment are relatively poorly understood, and that there are still large uncertainties in the relationship between constructed ecosystems and human well-being, it is not surprising that urbanization has resulted in many unanticipated consequences. Cities are very complex ecosystems, and actions directed at one component of the system often have surprising effects on other components. The Millennium Ecosystem Assessment noted that actions meant to enhance one ecosystem service often lead to unintentional degradation of other services (Millennium Ecosystem Assessment, 2005). Similarly, many problems faced by modern cities are a consequence of previous attempts to improve urban environmental and social conditions. The combustion engine, the largest source of many types of urban air pollution, was seen a century ago as a solution to the public health problems presented by the horse and buggy (Nikiforuk, 2013). As cities move forward with new, proposed solutions to modern urban problems, even "green" solutions involving enhanced ecosystem services and green infrastructure may lead to unintended consequences when these technologies are implemented at large scales.
A closer association between urban ecology and the practice of planning, designing, and managing cities may avoid or mitigate some of these consequences. From a scientific perspective, a systems-level understanding of the functioning of cities is greatly enhanced by inclusion of stakeholders who are experts in the political, social, and policy dimensions of a given urban area. From a translational perspective, urban ecosystem science can be put into practice more rapidly when ecologists inform the planning process through the development and testing of sharing research questions, robust tools, and place-specific ecological data (James et al., 2009; Lovell and Taylor, 2013) as well as scientifically sound landscape and site designs (Felson and Pickett, 2005; Pickett and Cadenasso, 2008; Ahern, 2013; Felson et al., 2013a; Steiner, 2014). These activities are increasingly iterative and adaptive, with experimental science and ecological monitoring integrated with actions that can feedback to decisionmaking via participatory planning, adaptive management, and the coproduction of knowledge at the science-policy interface (Pickett et al., 2004; Pickett and Cadenasso, 2008; Lovell and Johnston, 2009; Evans, 2011; Felson et al., 2013b; Lovell and Taylor, 2013; Ahern et al., 2014; Niemelä, 2014). Such interactions take advantage of a shared understanding developed in the fields of both ecology and planning that cities are complex systems; that they are dynamic over space and time; and that they interact with their surroundings regionally and globally. Critically, the application of urban ecology into practice places a high bar on our understanding of ecology as a science, which must be robust enough to successfully design and maintain well-functioning, constructed ecosystems.

\section{Conclusions}

Many differences between urban ecology and the study of other types of ecosystems stem from the fact that urban ecosystems are intentionally created. And yet, they often function in surprising and unanticipated ways. Ecology is a systems science that is well-aligned with understanding urban complexity and the interacting components, feedbacks, and non-linear dynamics of cities. While a lack of integration between the fields of human and biological ecology limited the early development of urban ecological and theory and methods relative to other disciplines, there has been great recent progress in integrating urban social and biophysical science. Nevertheless, there are still limitations to translating these results into usable information for practitioners, as the urban ecological literature increasingly demonstrates that interactions among the human, non-human, and abiotic components of cities are highly place-, site-, and species-specific. The field faces new grand challenges as cities move toward largescale implementation of actions, policies, and designs influenced by ecological concepts. It will be incumbent upon the scientific community to deliver rigorous urban ecological research in the forms of theoretical advances, model development and testing, well-designed experiments and monitoring, and close collaborations between scientists, practitioners, and stakeholders so that the "greener" cities of the twenty first century can be based on the best available science. 


\section{Acknowledgments}

This synthesis was based on U.S. National Science Foundation grants DEB 0919381, EAR 1204442, and EF

\section{References}

Ahern, J. (2013). Urban landscape sustainability and resilience: the promise and challenges of integrating ecology with urban planning and design. Landsc. Ecol. 28, 1203-1212. doi: 10.1007/s10980-0129799-z

Ahern, J., Cilliers, S., and Niemelä, J. (2014). The concept of ecosystem services in adaptive urban planning and design: a framework for supporting innovation. Landsc. Urban Plan. 125, 254-259. doi: 10.1016/j.landurbplan.2014. 01.020

Alberti, M. (2007). Urban patterns and environmental performance: what do we know? J. Plan. Educ. Res. 19, 151-163. doi: 10.1177/0739456X99019 00205

Alberti, M., Marzluff, J. M., Shulenberger, E., Bradley, G., Ryan, C., and Zumbrunnen, C. (2003). Integrating humans into ecology: opportunities and challenges for studying urban ecosystems. Bioscience 53, 1169-1179. doi: 10.1641/0006-3568(2003)053[1169:IHIEOA]2.0.CO;2

Breuste, J. H. (2004). Decision making, planning and design for the conservation of indigenous vegetation within urban development. Landsc. Urban Plan. 68, 439-452. doi: 10.1016/S0169-2046(03)00150-6

Cameron, W. F., Blanusa, T., Taylor, J. E., Salisbury, A., Halstead, A. J., Henricot, B., et al. (2012). The domestic garden - Its contribution to urban green infrastructure. Urban For. Urban Gree. 11, 129-137. doi: 10.1016/j.ufug.2012.01.002

Carpenter, S. R., Mooney, H. A., Agard, J., Capistrano, D., DeFries, R. S., Diaz, S., et al. (2009). Science for managing ecosystem services: beyond the millennium ecosystem assessment. Proc. Natl. Acad. Sci. U.S.A. 106, 1305-1312. doi: 10.1073/pnas.0808772106

Chowdhury, R. R., Larson, L., Grove, M., Polsky, C., Cook, E., Onsted, J., et al. (2011). A multi-scalar approach to theorizing socio-ecological dynamics of urban residential landscapes. Cities Environ. 4:6.

Clarke, L. W., Jenerette, G. D., and Davila, A. (2013). The luxury of vegetation and the legacy of tree biodiversity in Los Angeles, CA. Landsc. Urban Plan. 116, 48-59. doi: 10.1016/j.landurbplan.2013.04.006

Dallimer, J., Irvine, K. N., Skinner, A. M. J., Davies, Z. G., Rouquette, J. R., Maltby, L. L., et al. (2012). Biodiversity and the feel-good factor: understanding associations between self-reported human well-being and species richness. Bioscience 62, 47-55. doi: 10.1525/bio.2012.62.1.9

Evans, J. P. (2011). Resilience, ecology and adaptation in the experimental city. Trans. Inst. Br. Geogr. 36, 223-237. doi: 10.1111/j.1475-5661.2010. 00420.x

Felson, A. J., Bradford, M. A., and Terway, T. (2013a). Promoting Earth stewardship through urban design experiments. Front. Ecol. Environ. 11, 362-367. doi: 10.1890/130061

Felson, A. J., Pavao-Zuckerman, M., Carter, T., Montalto, F., Shuster, B., Springer, N., et al. (2013b). Mapping the design process for urban ecology researchers. Bioscience 63, 854-865. doi: 10.1525/bio.2013.63.11.4

Felson, A. J., and Pickett, S. T. A. (2005). Designed experiments: new approaches to studying urban ecosystems. Front. Ecol. Environ. 3 549-556. doi: 10.1890/1540-9295(2005)003[0549:DENATS]2. $0 . \mathrm{CO} ; 2$

Formann, R. T. T. (2014). Urban Ecology: Science of Cities. Cambridge, MA: Cambridge University Press.

Gill, S. E., Handley, J. F., Ennos, A. R., and Pauleit, S. (2007). Adapting cities for climate change: the role of the green infrastructure. Built Environ. 33, 115-133. doi: 10.2148/benv.33.1.115

Goddard, M. A., Dougill, A. J., and Benton, T. G. (2010). Scaling up from gardens: biodiversity conservation in urban environments. Trends Ecol. Evol. 25, 90-98. doi: $10.1016 /$ j.tree.2009.07.016
1065831. Any opinions, findings, and conclusions or recommendations expressed are those of the author and do not necessarily reflect the views of the National Science Foundation.
Grimm, N. B., Grove, J. M., Pickett, S. T. A., and Redman, C. L. (2000). Integrated approaches to long-term studies of urban ecological systems. Bioscience 50, 571-584. doi: 10.1641/0006-3568(2000)050[0571:IATLTO]2.0.CO;2

Grimm, N. B., and Redman, C. L. (2004). Approaches to the study of urban ecosystems: the case of Central Arizona-Phoenix. Urban Ecosyst. 7, 199-213. doi: 10.1023/B:UECO.0000044036.59953.a1

Groffman, P. M., Cavendar-Bares, J., Bettez, N. D., Grove, J. M., Hall, S. J., Heffernan, J. B., et al. (2014). Ecological homogenization of urban USA. Front. Ecol. Environ. 12, 74-81. doi: 10.1890/120374

Hermy, H., and Cornelis, J. (2000). Towards a monitoring method and a number of multifaceted and hierarchical biodiversity indicators for urban and suburban parks. Landsc. Urban Plan. 49, 149-162. doi: 10.1016/S0169-2046(00) 00061-X

Higgs, E. (2012). “Changing nature: novel ecosystems, intervention, and knowing when to step back," in Sustainability Science, eds M. P. Weinstein and R. E. Turner (New York, NY: Springer), 383-398.

Hobbs, R. J., Arico, S., Aronson, J., Baron, J. S., Bridgewater, P., Cramer, V. A., et al. (2006). Novel ecosystems: theoretical and management aspects of the new ecological world order. Glob. Ecol. Biogeogr. 15, 1-7. doi: 10.1111/j.1466822X.2006.00212.x

Hobbs, R. J., Higgs, E., and Harris, J. A. (2009). Novel ecosystems: implications for conservation and restoration. Trends Ecol. Evol. 24, 599-605. doi: 10.1016/j.tree.2009.05.012

Hostetler, M., Allen, W., and Meurk, C. (2011). Conserving urban biodiversity? Creating green infrastructure is only the first step. Landsc. Urban Plan. 100, 369-371. doi: 10.1016/j.landurbplan.2011.01.011

James, P., Tzoulas, K., Adams, M. D., Barber, A., Box, J., Brueste, J., et al. (2009). Towards an integrated understanding of green space in the European built environment. Urban For. Urban Gree. 8, 65-75. doi: 10.1016/j.ufug.2009. 02.001

Jenerette, G. D., Miller, G., Buyantuev, A., Pataki, D. E., Gillespie, T. W., and Pincetl, S. (2013). Urban vegetation and income segregation in drylands: a synthesis of seven metropolitan regions in the southwestern United States. Environ. Res. Lett. 8:044001. doi: 10.1088/1748-9326/8/4/044001

Jin, W., Xu, L., and Yang, Z. (2009). Modeling a policy making framework for urban sustainability: incorporating system dynamics into the ecological footprint. Ecol. Econ. 68, 2938-2949. doi: 10.1016/j.ecolecon.2009.06.010

Jorgensen, A., and Gobster, P. H. (2010). Shades of green: measuring the ecology of urban green space in the context of human health and well-being. Nat. Cult. 5, 338-363. doi: 10.3167/nc.2010.050307

Kareiva, P., Watts, S., McDonald, R., and Boucher, T. (2007). Domesticated nature: shaping landscapes and ecosystems for human welfare. Science 316, 1866-1869. doi: $10.1126 /$ science. 1140170

Kaye, J. P., Groffman, P. M., Grimm, N. B., Baker, L. A., Pouyat, R. V., et al. (2006). A distinct urban biogeochemistry? Trends Ecol. Evol. 21, 192-199. doi: 10.1016/j.tree.2005.12.006

Kembel, S. W., Jones, E., Kline, J., Northcutt, D., Stenson, J., Womack, A. M., et al. (2012). Architectural design influences the diversity and structure of the built environment microbiome. ISME J. 6, 1469-1479. doi: 10.1038/ismej. 2011.211

Kendal, D., Williams, N. S. G., and Williams, K. J. H. (2012). A cultivated environment: exploring the global distribution of plants in gardens, parks and streetscapes. Urban Ecosyst. 15, 637-652. doi: 10.1007/s11252-011-0215-2

Kennedy, C., Pincetl, S., and Bunje, P. (2011). The study of urban metabolism and its applications to urban planning and design. Environ. Pollut. 159, 1965-1973. doi: 10.1016/j.envpol.2010.10.022

Kennedy, C., Steinberger, J., Gasson, B., Hansen, Y., Hillman, T., Havranek, M., et al. (2009). Greenhouse gas emissions from global cities. Environ. Sci. Technol. 43, 7297-7302. doi: 10.1021/es900213p 
King, G. (2014). Urban microbiomes and urban ecology: how do microbes in the built environment affect human sustainability in cities? J. Microbiol. 52, 721-728. doi: 10.1007/s12275-014-4364-x

Konya, T., and Scott, J. A. (2014). Recent advances in the microbiology of the built environment. Curr. Sustainable/Renewable Energy Rep. 1, 35-42. doi: 10.1007/s40518-014-0007-4

Kowarik, I. (2011). Novel urban ecosystems, biodiversity and conservation. Environ. Pollut 159, 8-9. doi: 10.1016/j.envpol.2011.02.022

Lee, A. C. K., and Maheswaran, R. (2011). The health benefits of urban green spaces: a review of them evidence. J. Public Health 33, 212-222. doi: 10.1093/pubmed/fdq068

Loram, A., Warren, P. H., and Gaston, K. J. (2008). Urban domestic gardens (XIV): the characteristics of gardens in five cities. Environ. Manage. 42, 361-376. doi: 10.1007/s00267-008-9097-3

Lovell, S. T., and Johnston, D. M. (2009). Designing landscapes for performance based on emerging principles in landscape ecology. Ecol. Soc. 14:44. Available online at: http://www.ecologyandsociety.org/vol14/iss1/art44/

Lovell, S. T., and Taylor, J. R. (2013). Supplying urban ecosystem services through multifunctional green infrastructure in the United States. Landsc. Ecol. 28, 1447-1463. doi: 10.1007/s10980-013-9912-y

Luck, M. A., Jenerette, G. D., Wu, J., and Grimm, N. B. (2001). The urban funnel model and the spatially heterogeneous ecological footprint. Ecosystems 4, 782-796. doi: 10.1007/s10021-001-0046-8

Lundholm, J. T., Weddle, B. M., and MacIvor, J. S. (2014). Snow depth and vegetation type affect green roof thermal performance in winter. Energ. Build. 84, 299-307. doi: 10.1016/j.enbuild.2014.07.093

Lyytimäki, J., Petersen, L. K., and Normander, B. (2008). Nature as a nuisance? Ecosystem services and disservices to urban lifestyle. Environ. Sci. 5, 161-172. doi: 10.1080/15693430802055524

MacIvor, J. S., Ranalli, M. A., and Lundholm, J. T. (2011). Performance of dryland and wetland plant species on extensive green roofs. Ann. Bot. 107, 671-679. doi: $10.1093 / \mathrm{aob} / \mathrm{mcr} 007$

Mazer, G., Booth, D., and Ewing, K. (2001). Limitations to vegetation establishment and growth in biofiltration swales. Ecol. Eng. 17, 429-443. doi: 10.1016/S09258574(00)00173-7

McDonnell, M. J. (2011). “The history of urban ecology: an ecologist's perspective," in Urban Ecology: Patterns, Processes, and Applications, eds J. Niemelä, J. H. Breuste, T. Elmqvist, G. Guntenspergen, P. James, and N. E. McIntyre (Oxford: Oxford University Press), 5-13.

McDonnell, M. J., Hahs, A. K., and Breuste, J. H. (2009). Ecology of cities and towns: A comparative approach. Cambridge, MA: Cambridge University Press.

McKain, K., Wofsy, S. C., Nehrkorn, T., Eluszkiewicz, J., Ehleringer, J. R., and Stephens, B. B. (2012). Assessment of ground-based atmospheric observations for verification of greenhouse gas emissions from an urban region. Proc. Natl. Acad. Sci. U.S.A. 109, 8423-8428. doi: 10.1073/pnas.1116 645109

Millennium Ecosystem Assessment. (2003). Ecosystems and Human Well-being: A Framework for Assessment. Washington, DC: Island Press.

Millennium Ecosystem Assessment. (2005). Ecosystems and Human Well-being: Synthesis. Washington, DC: Island Press.

Moffett, S., and Kohler, N. (2008). Conceptualizing the built environment as a social-ecological system. Build. Res. Inf. 36, 248-268. doi: $10.1080 / 09613210801928131$

Morse, N. B., Pellissier, P. A., Cianciola, E. N., Brereton, R. L., Sullivan, M. M., Shonka, N. K., et al. (2014). Novel ecosystems in the Anthropocene: a revision of the novel ecosystem system for pragmatic applications. Ecol. Soc. 19:12. doi: 10.5751/ES-06192-190212

Murcia, C., Aronson, J., Kattan, G. H., Moreno-Mateos, D., Dixon, K., and Simberloff, D. (2014). A critique of the 'novel ecosystem' concept. Trends Ecol. Evol. 29, 548-553. doi: 10.1016/j.tree.2014.07.006

Newman, P. W. G. (1999). Sustainability and cities: extending the metabolism model. Landsc. Urban Plan. 44, 219-226. doi: 10.1016/S0169-2046(99) 00009-2

Niemelä, J. (1999). Is there a need for a theory of urban ecology? Urban Ecosyst. 3, 57-65.

Niemelä, J. (2014). Ecology of urban green spaces: the way forward in answering major research questions. Landsc. Urban Plan. 125, 298-303. doi: 10.1016/j.landurbplan.2013.07.014
Nikiforuk, A. (2013, March 6). The big shift last time: From horse dung to car smog. The Tyee, Available online at: http://thetyee.ca/News/2013/03/06/HorseDung-Big-Shift/

Oberndorfer, E., Lundholm, J., Bass, B., Coffman, R. R., Doshi, H., Dunnett, N., et al. (2007). Green roofs as urban ecosystems: ecological structures, functions, and services. Bioscience 57, 823-833. doi: 10.1641/B571005

Park, R. E., Burgess, E. W., and McKenzie, R. D. (1925). The City. Chicago, IL: University of Chicago Press.

Pataki, D. E., Alig, R. J., Fung, A. S., Golubiewski, N. E., Kennedy, C. A., McPherson, E. G., et al. (2006). Urban ecosystems and the North American carbon cycle. Glob. Change Biol. 12, 2092-2101. doi: 10.1111/j.13652486.2006.01242.x

Pataki, D. E., Boone, C. G., Hogue, T. S., Jenerette, G. D., McFadden, J. P., and Pincetl, S. (2011a). Socio-ecohydrology and the urban water challenge. Ecohydrology 4, 341-347. doi: 10.1002/eco.209

Pataki, D. E., Carreiro, M. M., Cherrier, J., Grulke, N. E., Jenning, V., Pincetl, S., et al. (2011b). Coupling biogeochemical cycles in urban environments: ecosystem services, green solutions, and misconceptions. Front. Ecol. Environ. 9, 27-36. doi: 10.1890/090220

Pickett, S. T. A., and Cadenasso, M. L. (2008). Linking ecological and built components of urban mosaics: an open cycle of ecological design. J. Ecol. 96, 8-12. doi: 10.1111/j.1365-2745.2007.01310.x

Pickett, S. T. A., Cadenasso, M. L., Grove, J. M., Nilon, C. H., Pouyat, R. V., Zipperer, W. C., et al. (2001). Urban ecological systems: linking terrestrial ecological, physical, and socioeconomic components of metropolitan area. Annu. Rev. Ecol. Syst. 32, 127-157. doi: 10.1146/annurev.ecolsys.32.081501.114012

Pickett, S. T. A., Cadenasso, M. L., and, Grove, J. M. (2004). Resilient cities: meaning, models, and metaphor for integrating the ecological, socioeconomic, and planning realms. Landsc. Urban Plan. 69, 369-384. doi: 10.1016/j.landurbplan.2003.10.035

Pincetl, S., Bunje, P., and Holmes, T. (2012). An expanded urban metabolism method: toward a systems approach for assessing urban energy processes and causes. Landsc. Urban Plan. 107, 193-202. doi: 10.1016/j.landurbplan.2012.06.006

Raudsepp-Hearne, C., Peterson, G. D., Tengo, M., Bennett, E. M., Holland, T., Benessiah, K., et al. (2010). Untangling the environmentalist's paradox: why is human well-being increasing as ecosystem services degrade? Bioscience 60, 576-589. doi: 10.1525/bio.2010.60.8.4

Reyers, B., Biggs, R., Cumming, G. S., Elmqvist, T., Hejnowicz, A. P., and Polasky, S. (2013). Getting the measure of ecosystem services: a social-ecological approach. Front. Ecol. Environ. 11, 268-273. doi: 10.1890/120144

Rudd, H., Vala, J., and Schaefer, V. (2002). Importance of backyard habitat in a comprehensive biodiversity conservation strategy: a connectivity analysis of urban green spaces. Restor. Ecol. 10, 368-375. doi: 10.1046/j.1526100X.2002.02041.x

Seastedt, T. R., Hobbs, R. J., and Suding, K. N. (2008). Management of novel ecosystems: are novel approaches required? Front. Ecol. Environ. 6, 547-553. doi: 10.1890/070046

Shahrokni, H., Lazarevic, D., and Brandt, N. (2015). Smart urban metabolism: towards a real-time understanding of the energy and material flows of a city and its citizens. J. Urban Tech. 22, 65-86. doi: 10.1080/10630732.2014. 954899

Shanahan, D. F., Lin, B. B., Bush, R., Gaston, K. J., Dean, J. H., Barber, E., et al. (2015). Toward improved public health outcomes from urban nature. Am. J. Public Health 105, 470-477. doi: 10.2105/AJPH.2014.302324

Steiner, F. (2014). Frontiers in urban ecological design and planning research. Landsc. Urban Plan. 125, 304-311. doi: 10.1016/j.landurbplan.2014.01.023

Sukopp, H. (2002). On the early history of urban ecology in Europe. Preslia Praha 74, 373-393. doi 10.1007/978-0-387-73412-5_6

Summers, J. K., Smith, L. M., Case, J. L., and Linthurst, R. A. (2012). A review of the elements of human well-being with an emphasis on the contribution of ecosystem services. Ambio 41, 327-340. doi: 10.1007/s13280-0120256-7

Syrbe, R.-U., and Walz, U. (2012). Spatial indicators for the assessment of ecosystem services: providing, benefiting, and connecting areas and landscape metrics. Ecol. Indic. 21, 80-88. doi: 10.1016/j.ecolind.2012. 02.013 
Tzoulas, K., Korpela, K., Venn, S., Yli-Pelkonen, V., Kaźmierczak, A., Niemela, J., et al. (2007). Promoting ecosystem and human health in urban areas using green infrastructure: a literature review. Landsc. Urban Plan. 81, 167-178. doi: 10.1016/j.landurbplan.2007. 02.001

van Kamp, I., Leidelmeijer, K., Marsman, G., and de Hollander, A. (2003). Urban environmental quality and human well-being: towards a conceptual framework and demarcation of concepts, a literature study. Landsc. Urban Plan. 65, 5-18. doi: 10.1016/S0169-2046(02) 00232-3

Velasco, E., and Roth, M. (2010). Cities as net sources of $\mathrm{CO}_{2}$ : review of atmospheric $\mathrm{CO}_{2}$ exchange in urban environments measured by eddy covariance technique. Geogr. Compass 4, 1238-1259. doi: 10.1111/j.17498198.2010.00384.x von Döhren, P., and Haase, D. (2015). Ecosystem disservices research: a review of the state of the art with a focus on cities. Ecol. Indic. 52, 490-497. doi: 10.1016/j.ecolind.2014.12.027

Conflict of Interest Statement: The author declares that the research was conducted in the absence of any commercial or financial relationships that could be construed as a potential conflict of interest.

Copyright (c) 2015 Pataki. This is an open-access article distributed under the terms of the Creative Commons Attribution License (CC BY). The use, distribution or reproduction in other forums is permitted, provided the original author(s) or licensor are credited and that the original publication in this journal is cited, in accordance with accepted academic practice. No use, distribution or reproduction is permitted which does not comply with these terms. 